\title{
Why do mortality rates for nonvariceal upper gastrointestinal bleeding differ around the world? A systematic review of cohort studies
}

\author{
Vipul Jairath BSc MBChB MRCP1,2, Myriam Martel BSc ${ }^{3}$, \\ Richard FA Logan MSc FRCP ${ }^{4}$, Alan N Barkun MD CM FRCPC MSc ${ }^{3,5}$
}

V Jairath, M Martel, RFA Logan, AN Barkun. Why do mortality rates for nonvariceal upper gastrointestinal bleeding differ around the world? A systematic review of cohort studies. Can J Gastroenterol 2012;26(8):537-543.

BACKGROUND: Discrepancies exist in reported mortality rates of nonvariceal upper gastrointestinal bleeding (NVUGIB).

OBJECTIVE: To perform a systematic review assessing possible reasons for these disparate findings and to more reliably compare them. METHODS: The MEDLINE, EMBASE and ISI Web of Knowledge databases were searched for studies reporting mortality rates in NVUGIB involving adults and published in English. To ensure robust and contemporary estimates, studies spanning 1996 to January 2011 that included more than 1000 patients were selected.

RESULTS: Eighteen of 3077 studies were selected. Ten studies used administrative databases and the remaining eight used registries. The mortality rates reported in these studies ranged from $1.1 \%$ in Japan to $11 \%$ in Denmark. There were variations in reported mortality rates among countries and also within countries. Reasons for these disparities included a spectrum of quality in reporting as well as heterogeneous definitions of case ascertainment, differing patient populations with regard to severity of presentation and associated comorbidities, varying durations of follow-up and different health care systemrelated practices.

CONCLUSIONS: Wide differences in reported NVUGIB mortality rates are attributable to differences in adopted methodologies and populations studied. More uniform standards in reporting are needed; only then can true observed variations enable a better understanding of causes of death and pave the way to improved patient outcomes.

Key Words: Acetylsalicylic acid; Acute gastrointestinal bleeding; Bleeding peptic ulcer; Gastrointestinal endoscopy

$\mathrm{N}$ onvariceal upper gastrointestinal bleeding (NVUGIB) is a common problem worldwide, with reports of its incidence ranging from 48 to 160 cases per 100,000 adults per year (1-3). NVUGIB is associated with considerable morbidity, mortality and economic impact, despite significant advances in its management over the past two decades. In the past two years, several publications have focused on the epidemiology and changing time trends of acute NVUGIB. Most of these studies have reported a reduction in its incidence and associated case fatality (henceforth referred to as 'mortality') rate (4-8), although some have reported no changes in mortality (9-11). The reductions in mortality observed over time have been largely attributed to combinations of therapeutic endoscopy, proton pump inhibitors, eradication of Helicobacter pylori, preventive strategies in individuals taking nonsteroidal anti-inflammatory drugs and advances in critical care. Because most patients do not die from uncontrolled

\author{
Pourquoi le taux de mortalité causée par les \\ hémorragies œsogastroduodénales non variqueuses \\ diffère-t-il de par le monde? Une analyse \\ systématique d'études de cohorte
}

HISTORIQUE : Il existe des écarts dans les taux de mortalité déclarés d'hémorragies œesogastroduodénales non variqueuses (HOGDNV).

OBJECTIF : Effectuer une analyse systématique pour évaluer les raisons possibles de ces observations disparates et les comparer de manière plus fiable.

MÉTHODOLOGIE : Les chercheurs ont effectué des recherches dans les bases de données MEDLINE, EMBASE et ISI Web of Knowledge pour trouver des études publiées en anglais précisant le taux de mortalité causée par les HOGDNV chez des adultes. Afin de garantir des évaluations robustes et contemporaines, les chercheurs ont sélectionné des études de plus de 1000 patients menées de 1996 à janvier 2011.

RÉSULTATS : Les chercheurs ont retenu 18 des 3077 études. Dix études faisaient appel à des bases de données administratives et les huit autres, à des registres. Le taux de mortalité déclarée dans ces études variait entre $1,1 \%$ au Japon et $11 \%$ au Danemark. On constatait des variations dans le taux de mortalité déclarée entre les pays et également dans un même pays. Les raisons de ces disparités incluaient un spectre de qualité des déclarations et des définitions hétérogènes d'évaluation des cas, des populations de patients différentes à l'égard de la gravité de la présentation et des comorbidités connexes, des durées de suivi variées et des pratiques différentes liées aux systèmes de santé.

CONCLUSIONS : Les grandes différences de taux de mortalité causée par les HOGDNV sont attribuables aux diverses méthodologies adoptées et populations étudiées. Des normes de déclaration plus uniformes s'imposent. Ce n'est qu'alors que les véritables variations observées permettront de mieux comprendre les causes de décès et d'améliorer les issues des patients.

bleeding $(12,13)$, further improvements in outcomes will be challenging in the face of an aging population with the associated burden of comorbidities. Several recent studies and reviews have served to highlight variations in mortality rates reported for NVUGIB, ranging from $3 \%$ to $12 \%$, as well as highlighting substantial differences in mortality among countries $(9,14-18)$. The studies reporting these outcomes range from prospectively collected national registries for NVUGIB to retrospective analyses of large administrative databases. Such marked differences in outcomes are surprising because most of these studies originate from health care systems with access to modern-day, evidence-based standards and processes of care for managing NVUGIB.

A range of factors can influence the survival of patients with NVUGIB including those related to patients, disease severity and health care systems. Comparisons among countries are fraught with difficulty due to the complexity and intricacy of factors influencing

${ }^{1}$ Translational Gastroenterology Unit, John Radcliffe Hospital; ${ }^{2}$ NHS Blood Eु Transplant, John Radcliffe Hospital, Oxford, United Kingdom; ${ }^{3}$ Division of

Gastroenterology, McGill University Health Centre, Montreal, Quebec; ${ }^{4}$ Division of Epidemiology and Public Health $\mathcal{E}$ Nottingham Digestive Disease

Centre, United Kingdom; ${ }^{5}$ Division of Clinical Epidemiology, McGill University Health Centre, Montreal, Quebec

Correspondence: Dr Vipul Jairath, Translational Gastroenterology Unit and NHS Blood and Transplant, John Radcliffe Hospital, Headley Way, Oxford,

United Kingdom. Telephone 44-1865-387906, fax 44-1865-387957, e-mail vipul.jairath@nhsbt.nhs.uk

Received for publication September 20, 2011. Accepted December 20, 2011 


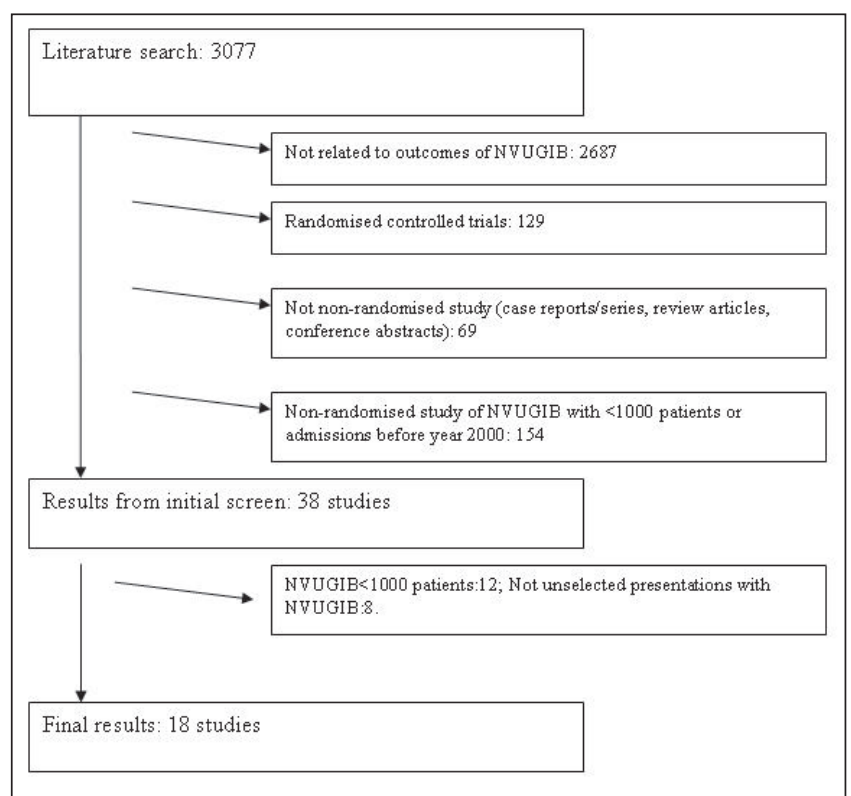

Figure 1) Search results. NVUGIB Nonvariceal upper gastrointestinal bleeding

mortality. We aimed to address possible reasons for the differences in reported mortality, and to more reliably compare current rates by systematically reviewing and appraising recent literature reporting mortality rates for acute NVUGIB, focusing on study methodology, source case ascertainment, reporting of key prognostic factors and quality of study reporting.

\section{METHODS}

\section{Search strategy}

The MEDLINE, EMBASE and ISI Web of Knowledge databases were searched for nonrandomized studies reporting mortality rates following presentation with NVUGIB. Search terms were combined with a highly sensitive observational study filter and restricted to include adult, human studies in English spanning 1996 to January 2011 (search terms can be provided on request). Reports preceding this period were not sought because of the significant evolution of general supportive care, and advances in endoscopic and pharmacological therapies that occurred during that time period (19); therefore, it was hypothesized that the chosen time period would represent a more homogenous group of data to compare. The bibliographies of identified articles were also screened.

\section{Eligibility criteria}

Cohort studies reporting mortality outcomes were searched for unselected patients presenting to hospital with acute NVUGIB. Only studies that reported outcomes for more than 1000 patients were included. For studies including both NVUGIB and acute variceal hemorrhage (AVH), only studies examining more than 1000 patients with NVUGIB were included. Studies published only as abstracts were excluded because they did not allow an adequate assessment of methodology. Citations identifed were screened in duplicate, with a kappa statistic of 0.65 (95\% CI 0.60 to 0.70). Following the development of a data abstraction sheet, results were extracted by two reviewers (VJ, $\mathrm{MM})$. Any disagreements were resolved by discussion and did not necessitate arbitration by a third person. Recorded information from each study included year of publication, study design, country of origin, nature of database analyzed, whether examining all-cause NVUGIB or a selected subgroup (eg, peptic ulcer bleeding only), age, new admission and/or inpatient bleeds, length of follow-up and mortality rate. Also assessed was the methodological quality of the study report, using criteria for the reporting of nonrandomized studies from the Cochrane Collaboration (20) and Strengthening The Reporting of Observational Studies in Epidemiology (STROBE) criteria for reporting of cohort studies (21).

\section{Data analysis}

Because the main aim of the present study was to examine differences in mortality rates and to attempt to identify the sources responsible for the variations observed, and because of the heterogeneity of the studies, only descriptive individual study data, without an attempt at formal meta-analysis, are provided. Indeed, the underlying assumption was that the mortality rate attributable to NVUGIB was not uniform, but rather, that it is dependent on a number of factors that are raised and outlined.

\section{Search results}

\section{RESULTS AND DISCUSSION}

The search yielded a total of 3077 articles, of which 3039 were excluded at the initial screen based on the title and abstract. The remaining 38 articles were reviewed in full for eligibility against prespecified criteria. An additional 20 studies were excluded, leaving 18 (11,12,14,16-18,22-33) in the final review. Reasons for exclusion are described in Figure 1.

\section{What are the reported mortality rates following NVUGIB?} The studies originated from Europe, Asia and North America (Table 1). The sources of data ranged from prospective cohort registries for peptic ulcer bleeding from single centres of expertise (12) to large retrospective cohorts from nationwide administrative data sets (14). Ten studies used administrative databases and the remaining eight used registries specifically designed to assess 'real-life' outcomes following NVUGIB, resulting in a mixture of retrospective and prospective cohort studies. The mortality rates reported in these studies ranged from $1.1 \%$ in Japan to $11 \%$ in Denmark. Not only was there variation in reported mortality among countries, there was notable variation reported within countries (Table 1).

\section{Why might reported mortality rates differ?}

Source of case ascertainment: Definitions of NVUGIB should be clear and consistent throughout studies to enable comparability. Completeness of case ascertainment and degree of population coverage will influence reported mortality. Three studies from Italy in the present review conducted over the same time period reported mortalities ranging from $2.6 \%$ to $6.9 \%(17,28,31)$. One study used administrative data (28) and the other two used registry data $(17,31)$. All three studies examined NVUGIB but definitions varied: two studies were reliant on retrospectively collected data coded by International Classification of Diseases, Ninth Revision (ICD-9)-CM $(28,31)$ discharge diagnoses including variations in the codes selected within each study, whereas the third study was a prospectively collated registry requiring confirmation of upper gastrointestinal tract bleeding by clinical examination by admitting medical/nursing personnel (17). Administrative databases, not designed for research, have the advantage of size and population-based longitudinal follow up, but accuracy of case ascertainment is dependent on coding. In addition, they are often unable to adjust for key disease-specific prognostic variables. Positive predictive values (PPVs) of ICD-9-CM coding for peptic ulcers and gastrointestinal bleeding have been shown to be reasonably accurate, with PPVs ranging from $85 \%$ to $95 \%$ (34), but differ depending on the terminology used (35-37). The terms with the greatest PPVs (>90\%) were for site-specific codes (eg, 'gastric' or 'duodenal' ulcer), but these were lower for lesion-specific codes (ie, 'peptic ulcer') and even lower for nonspecific terms such as 'melena' or 'hematemesis' (34). In addition, coding errors have been demonstrated in up to $7 \%$ of cases (34), which may result in thousands of miscoded cases in large datasets. This was fittingly highlighted in an article by Ahsberg et al (18), who stated "we found a sudden increase in hospitalisations for ulcer UNS (unspecified) after 1997, and at the same time-point, there was a large drop in hospitalisations for bleeding and perforated ulcers. These changes 
TABLE 1

Studies detailed according to preselected reporting characteristics that may influence observed mortality rates

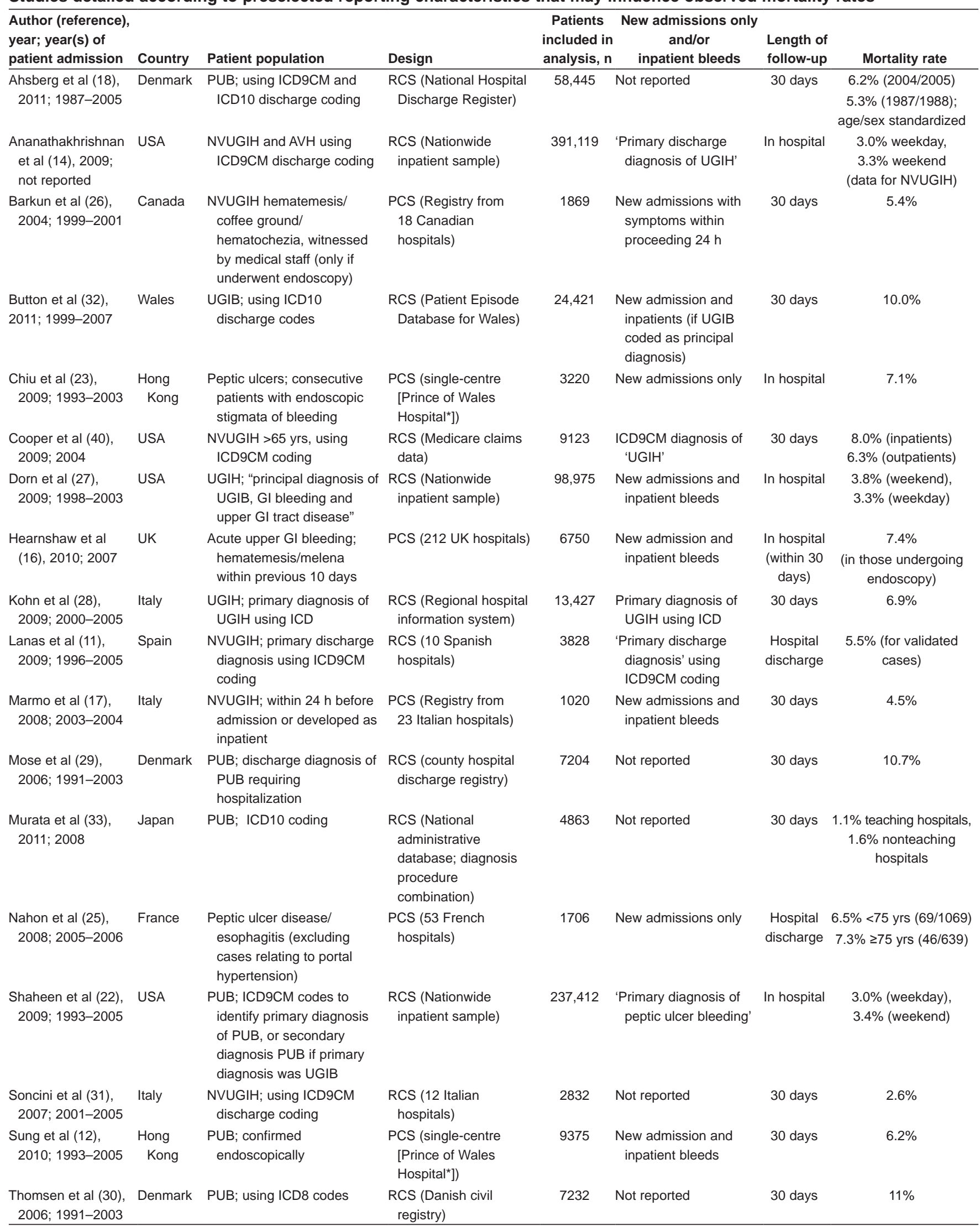

*Sha Tin, New Territories, Hong Kong. AVH Acute variceal hemorrhage; GI Gastrointestinal; ICD International Classification of Diseases; NVUGIH Nonvariceal upper gastrointestinal hemorrhage; PCS Prospective cohort study; PUB Peptic ulcer bleeding; RCS Retrospective cohort study; UGIB Upper gastrointestinal bleeding; UGIH Upper gastrointestinal hemorrhage; UK United Kingdom; yrs Years of age 
coincided with the introduction of [the] ICD-10 classification system....". Careful attention to selection of well-validated coding is key to enable accurate interpretation of outcome data from such administrative databases. Use of specific registries for NVUGIB, although labour and cost intensive, enable rigorous selection of cases, usually by medical and nursing personnel, ideally prospective follow-up, adjustment for key disease-specific prognostic variables and auditing of case ascertainment $(12,17,26)$, although they can be limited by size and inadequate population coverage.

Admission status and duration of reported patient follow-up: Careful review of selection criteria, patient sampling and length of follow-up also demonstrates subtle but important differences that may influence reported outcomes. For example, exploratory data have suggested differing health care delivery patterns between outpatient bleeds and cases in whom hemorrhage started while already hospitalized for an unrelated condition (38). Therefore, inclusion of inpatient bleeds will influence reported mortality rates considering their markedly poorer prognosis (38), with some series reporting up to a fourfold increase in mortality for inpatients developing bleeding compared with new admissions (39). One of the three Italian studies included both new admissions and existing inpatients who developed upper gastrointestinal tract bleeding (17), whereas it was unclear in the other two studies whether inpatient bleeds were included in addition to new admissions $(28,31)$. Three studies from the United States were included, with the study by Cooper et al (40) reporting almost double the mortality rate compared with the other two studies $(14,22)$. There were subtle differences in all three studies: all used administrative data-sets and ICD-9-CM coding to identify cases; Cooper et al (40) used Medicare claims data whereas the other two studies used data from the Nationwide Inpatient Sample (NIS) $(9,21)$. The study by Cooper reported 30-day mortality, in contrast to inhospital mortality reported by the other two studies. Unfortunately, without direct and uniform statistical adjustment for confounders among studies, one can only speculate whether such disparities can account for the twofold differences in reported mortality within countries.

Patient-related factors: Age and presence of comorbid illnesses are highly influential prognostic factors following presentation with NVUGIB, and critical components of risk assessment scores. Age is a component of the Rockall score (41), and the presence of comorbid illnesses are key components of both the Rockall and Blatchford scores (42), both extensively validated prognostic scores following NVUGIB in a variety of global patient populations and clinically meaningful to the practicing clinician. Although we are not advocating a particular score, although one should be used routinely in clinical practice, there is increasing evidence that the Blatchford score is more useful than the Rockall score in predicting the need for endoscopic therapy, transfusion and identifying patients at low risk for discharge, but not superior to the complete Rockall score in predicting mortality $(43,44)$. For valid comparisons of mortality rates, risk adjustment according to such factors is essential because these important prognosticators of outcome are unevenly distributed across providers and variation in baseline status could make a major contribution to observed differences in mortality rates. Risk adjustment is a complex construct that can involve patient's sociodemographic factors (eg, age, sex and race), acute clinical stability, severity of primary disease, functional status and burden of comorbidity (45). As highlighted in Table 2, there was remarkable similarity in the central measures of age in the reviewed studies, ranging from 64 to 74 years. However, there was wide variation in the characterization of comorbid illnesses, with specific NVUGIB registries more likely to detail individual comorbid illnesses, whereas administrative data sets were more likely to present composite scores such as the Charslon index (46) - a measure that is less clinically meaningful to the practicing clinician and not well validated as a component of risk-adjustment scores for NVUGIB. The Charlson comorbidity index was originally designed as a measure of the risk of one-year mortality attributable to comorbidity in a longitudinal study of generalized hospitalized patients, subsequently adapted so that
ICD-9 codes could be used to calculate the index with existing administrative data. The presenting international normalized ratio (INR) has also been suggested as a useful predictor of mortality and may be a more objectively measurable proxy of comorbidity (47). A more widespread use of validated prognostic scales (and their subsequent reporting in observational studies) has been recommended $(48,49)$ but remains very low $(<2 \%$ in a recent national study [50]). It is, therefore, disappointing - but not surprising - that only two studies presented the Rockall score $(16,31)$ and none presented the Blatchford score. Given this wide variation in characterization of comorbidities, it is difficult to make meaningful adjustments of baseline risk, hampering any ability to compare mortality rates among these studies or riskadjust the reported information accordingly.

Ethnicity and genetic factors may also play a role. Two studies involved Asian populations while the remainder assessed western populations (Table 1). Differences among these ethnic groups may affect outcomes based on varying rates of proton pump inhibitor metabolism, $H$ pylori prevalence, gastric parietal cell mass and disease acuteness, which may further limit direct comparisons of mortality (49).

Disease-related factors: Adequate risk adjustment to facilitate comparison of mortality also requires disease-specific risk adjustment. For NVUGIB, this would include the ability to adjust for features of hemodynamic shock, presenting hemoglobin/biochemical parameters, endoscopic diagnosis and stigmata of bleeding, including stigmata, that would be predictive of rebleeding. Only four of 18 studies presented all of these features, with 10 of 18 presenting none; administrative data sets were less likely to present this information. The inability to characterize disease acuity is a major limitation of many of the studies we reviewed, which further limits any direct comparison of outcomes among studies.

Health care system-related factors: It is, of course, probable that there are important differences in standards and procedures of care for NVUGIB that may account for some of the differences reported in mortality rates. These include the extent of access to emergency and resuscitative care, to timely endoscopy and available operator skills in hemostatic procedures and, in some cases, availability of surgery or radiological procedures, all of which may influence case fatality. Recent data from the United Kingdom (UK) has highlighted deficiencies in the provision of timely endoscopy for NVUGIB, with only $50 \%$ of hospitals having formal provision of a $24 \mathrm{~h}$ endoscopy service and $42 \%$ of high-risk patients (Rockall score $\geq 5$ ) waiting more than $24 \mathrm{~h}$ for their index endoscopy (16). This is in contrast to other national registries in which at least $70 \%$ of endoscopies were performed within $24 \mathrm{~h}$ of admission $(1,15,17,51)$. The actual national nature and representativeness of contributing sites may explain at least some of this variation.

The timeframe for performance of endoscopy may also play a role. Although there is some randomized evidence suggesting that timely endoscopy reduces transfusion requirements and duration of hospital stay (52), only more recent observational data have suggested an associated decrease in the need for surgery (24), although its impact on mortality remains uncertain and is an area for further research. The large, recently published UK audit barely failed to show an improvement in mortality associated with the availability of an after-hours endoscopy service (16). Several recent publications have also demonstrated increased mortality for patients admitted with NVUGIB on the weekend compared with a weekday $(14,22,27)$, as has been reported for other acute medical conditions (53-55), which may have implications for processes and models of care in those countries, although other countries (France, Hong Kong, UK) have not reported such associations for NVUGIB (56-58).

\section{Were studies reported well?}

Clear reporting is necessary to enable an accurate assessment of the strengths/weaknesses in study design, conduct and analysis. The quality of reporting of randomized controlled trials has improved several years after the endorsement of the Consolidated Standards of Reporting 
TABLE 2

Assessment of patient characteristics and disease severity

\begin{tabular}{|c|c|c|c|c|c|c|c|}
\hline \multirow[b]{2}{*}{$\begin{array}{l}\text { Author (reference), } \\
\text { year }\end{array}$} & \multirow[b]{2}{*}{$\begin{array}{l}\text { Age of analyzed } \\
\text { patients, years } \\
\text { (mean } \pm \text { SD or } \\
\text { median [IQR]) }\end{array}$} & \multirow[b]{2}{*}{$\begin{array}{l}\text { Comorbidities } \\
\text { characterized, } n\end{array}$} & \multicolumn{5}{|c|}{ Describes } \\
\hline & & & $\begin{array}{c}\text { Baseline } \\
\text { patient } \\
\text { characteristics, } \\
\mathbf{n} \\
\end{array}$ & $\begin{array}{c}\text { Presenting } \\
\text { hemodynamic } \\
\text { parameters }\end{array}$ & $\begin{array}{c}\% \text { presenting } \\
\text { with } \\
\text { hematemesis }\end{array}$ & $\begin{array}{c}\text { Presenting } \\
\text { hemotological/ } \\
\text { biochemical } \\
\text { parameters }\end{array}$ & $\begin{array}{c}\% \text { with } \\
\text { high-risk } \\
\text { endoscopic } \\
\text { stigmata }\end{array}$ \\
\hline $\begin{array}{l}\text { Ahsberg et al (18), } \\
2011\end{array}$ & Presented as age groups & None & 0 & No & No & No & No \\
\hline $\begin{array}{l}\text { Ananthakrishnan et al } \\
\text { (14), } 2009\end{array}$ & $\begin{array}{l}\text { Not reported (presented } \\
\text { as age groups) }\end{array}$ & $\begin{array}{l}\text { Charlson comorbidity index } \\
\text { (Deyo modification) }\end{array}$ & 5 & No & No & No & No \\
\hline Button et al (32), 2011 & 64.1 (95\% Cl 63.9-64.4) & 6 & 3 & No & No & No & No \\
\hline Chiu et al (23), 2009 & $41.8 \%>70$ years of age & $\begin{array}{l}14 \text { state number with } \\
>1 \text { comorbidity }\end{array}$ & 13 & Yes & Yes & Yes & Yes \\
\hline Cooper et al (40), 2009 & $78.2 \pm 0.8$ & Comorbidity index & 9 & No & No & No & No \\
\hline $\begin{array}{l}\text { Hearnshaw et al (16), } \\
2010\end{array}$ & $68(49-81)$ & $\begin{array}{l}8 \text { as well as presenting } \\
\text { Rockall score }\end{array}$ & 6 & Yes & No & No & Yes \\
\hline Kohn et al (28), 2009 & $68.0(16.8)$ & 9 & 5 & No & No & No & No \\
\hline Lanas et al (9), 2009 & $\begin{array}{c}74.3 \pm 13.7 \text { (fatal cases, } \\
\text { upper/lower Gl events } \\
\text { combined); } 64.8 \pm 18.4 \\
\text { (nonfatal cases) }\end{array}$ & $\begin{array}{l}\text { Details mean number of } \\
\text { comorbidities }\end{array}$ & 7 & No & No & Yes & No \\
\hline Marmo et al (17), 2008 & $\begin{array}{l}68 \pm 16 \\
70(53-81)\end{array}$ & $\begin{array}{l}\text { Mean number of } \\
\text { comorbidities; ASA score }\end{array}$ & 8 & Yes & Yes & Yes & Yes \\
\hline Mose et al (29), 2006 & $71(62-82)$ & Charlson index & 7 & No & No & No & No \\
\hline Murata et al (33), 2011 & $\begin{array}{l}64.7 \pm 17.8 \\
64.2 \pm 18.1\end{array}$ & Charlson comorbidity index & 7 & No & No & No & No \\
\hline $\begin{array}{l}\text { Thomsen et al (30), } \\
2006\end{array}$ & $74(62-82)$ & Charlson comorbidity index & 6 & No & No & No & No \\
\hline
\end{tabular}

ASA American Society of Anesthesiologists; GI Gastrointestinal; IQR Interquartile range

Trials (CONSORT) statement $(59,60)$ by researchers and journals. However, in observational research, important information is often missing or unclear (21), which has prompted the development of the STROBE consensus statements with the aim of helping authors and journals improve methods and quality of reporting of observational studies (21). In the present review, there were notable omissions when assessing quality of reporting (Table 3 ). The proportion of inversus outpatient onset of bleeding was unclear in 10 of 18 studies, and only one report provided a justification of sample size. Overall, 15 of 18 studies provided no information on missing data and how these were handled. Only four studies commented on processes for source data verification, while eight made no comments about the external validity of the reported data. Given the relatively large number of studies examining outcomes for NVUGIB, the development of a framework, similar to that recently developed to aid design and conduct of randomized controlled trials in NVUGIB (61), would help standardize reporting and enable more accurate comparisons of international data.

\section{FUTURE DIRECTIONS}

Improving reporting

Mortality following NVUGIB from most data sources remains substantial and is influenced by a multitude of patient-, disease- and health care system-related factors (Table 4). The present systematic review of available data on NVUGIB mortality suggests that investigators should strive to provide detailed descriptions of prognostic patient factors, process of care and methodological information to better inform any attempts at national comparisons of outcomes in NVUGIB. More uniform and standardized reporting is needed to facilitate baseline risk adjustment. In this respect, it would be helpful for studies to present, where possible, validated and clinically meaningful risk scores such as the Rockall (41) or Glasgow Blatchford scale (62), which incorporate both background comorbidities and acute disease acuity. For administrative data, validation of composite indexes, such as Charlson (46) and Elixhauser (63) in the setting of NVUGIB, would be helpful. As a minimum, the criteria presented in Table 3 would aid clarity and quality of reporting. 
TABLE 3

\section{Quality of reporting assessment $(n=18)$}

\begin{tabular}{lc}
\hline & Studies, $\mathbf{n}$ \\
\hline Description of eligibility criteria & 18 \\
Description of source of participants & 18 \\
Explains derivation of sample size & 1 \\
Description of statistical methods & 18 \\
Description of methods to examine & 16 \\
$\quad$ subgroups/interactions & \\
Description of methods of handling missing data & 3 \\
Discussion of data quality checks/source data verification & 4 \\
Discussion of limitations of study & 17 \\
Discussion of external validity of results & 8 \\
Discussion of source/role of funder & 14 \\
\hline
\end{tabular}

TABLE 4

Possible factors influencing mortality (case fatality rate) following nonvariceal upper gastrointestinal bleeding

\begin{tabular}{|c|c|}
\hline \multirow[t]{4}{*}{ Patient related } & Age, sex \\
\hline & $\begin{array}{l}\text { Diagnostic mix (ie, percentage with malignancy, percentage } \\
\text { with liver disease) }\end{array}$ \\
\hline & $\begin{array}{l}\text { Population comorbidity (ie, percentage of smokers, } \\
\text { percentage with cardiovascular disease) }\end{array}$ \\
\hline & $\begin{array}{l}\text { Prevalence of pro- and antibleeding drug use (eg, } \\
\text { acetylsalicylic acid use, proton pump inhibitor use, } \\
\text { warfarin) }\end{array}$ \\
\hline \multirow{6}{*}{$\begin{array}{l}\text { Health service } \\
\text { related }\end{array}$} & Resuscitation facilities \\
\hline & Use of blood \\
\hline & Availability of endoscopy with therapeutic intervention \\
\hline & $\begin{array}{l}\text { Time to endoscopy (although no clear evidence yet that this } \\
\text { is a true prognostic factor) }\end{array}$ \\
\hline & $\begin{array}{l}\text { Use of surgery (ie, a high surgical rate could increase } \\
\text { mortality) }\end{array}$ \\
\hline & Speed of access to secondary care \\
\hline \multirow[t]{4}{*}{ Technical } & Case ascertainment/population based \\
\hline & $\begin{array}{l}\text { Restricted to acute gastrointestinal bleeding only (chronic } \\
\text { bleeding defined and excluded) }\end{array}$ \\
\hline & Acute admissions clearly separated from inpatient bleeding \\
\hline & Adequate sample size \\
\hline
\end{tabular}

\section{Improving outcomes}

Reducing mortality further will be challenging in the face of an aging population and may depend on improved adherence to existing international recommendations (48) (which are currently poorly adhered to [64]), perhaps coupled to the emergence of important data on optimal resuscitation with blood components $(65,66)$, and promising novel diagnostic $(67,68)$ and therapeutic technologies $(69)$.

\section{CONCLUSIONS}

The present review demonstrated wide differences in reported mortality rates from NVUGIB. We suggest that these differences are largely attributable to differences in adopted methodologies and populations studied. More uniform standards in reporting are needed; only then can true observed variations allow a better understanding of causes of death and pave the way to improved patient outcomes.

\section{REFERENCES}

1. van Leerdam ME, Vreeburg EM, et al. Acute upper GI bleeding: Did anything change? Time trend analysis of incidence and outcome of acute upper GI bleeding between 1993/1994 and 2000. Am J Gastroenterol 2003;98:1494-9.
2. Lassen A, Hallas J, Schaffalitzky de Muckadell OB. Complicated and uncomplicated peptic ulcers in a Danish county 1993-2002: A population-based cohort study. Am J Gastroenterol 2006;101:945-53.

3. Targownik LE, Nabalamba A. Trends in management and outcomes of acute nonvariceal upper gastrointestinal bleeding: 1993-2003. Clin Gastroenterol Hepatol 2006;4:1459-66.

4. Sung JJ, Kuipers EJ, El-Serag HB. Systematic review: The global incidence and prevalence of peptic ulcer disease. Aliment Pharmacol Ther 2009;29:938-46.

5. Chiu PW, Sung JJ. Acute nonvariceal upper gastrointestinal bleeding. Curr Opin Gastroenterol 2010;26:425-8.

6. Loperfido S, Baldo V, Piovesana E, et al. Changing trends in acute upper-GI bleeding: A population-based study. Gastrointest Endosc 2009;70:212-24.

7. Wang YR, Richter JE, Dempsey DT. Trends and outcomes of hospitalizations for peptic ulcer disease in the United States, 1993 to 2006. Ann Surg 2010;251:51-8.

8. Hermansson M, Ekedahl A, Ranstam J, Zilling T. Decreasing incidence of peptic ulcer complications after the introduction of the proton pump inhibitors, a study of the Swedish population from 1974-2002. BMC Gastroenterol 2009;9:25.

9. Lanas A. Editorial: Upper GI bleeding-associated mortality: Challenges to improving a resistant outcome. Am J Gastroenterol 2010;105:90-2.

10. Ahsberg K, Hoglund P, Stael von Holstein C. Mortality from peptic ulcer bleeding: The impact of comorbidity and the use of drugs that promote bleeding. Aliment Pharmacol Ther 2010;32:801-10.

11. Lanas A, Garcia-Rodriguez LA, Polo-Tomas M, et al. Time trends and impact of upper and lower gastrointestinal bleeding and perforation in clinical practice. Am J Gastroenterol 2009;104:1633-41.

12. Sung JJ, Tsoi KK, Ma TK, Yung MY, Lau JY, Chiu PW. Causes of mortality in patients with peptic ulcer bleeding: A prospective cohort study of 10,428 cases. Am J Gastroenterol 2010;105:84-9.

13. Jairath V, Logan R, Hearnshaw S, Travis S, Murphy M, Palmer K. Acute upper gastrointestinal bleeding - why do patients die? Gastroenterology 2010;138(Suppl 1):637-8 (Abst).

14. Ananthakrishnan AN, McGinley EL, Saeian K. Outcomes of weekend admissions for upper gastrointestinal hemorrhage: A nationwide analysis. Clin Gastroenterol Hepatol 2009;7:296-302e1.

15. Barkun AN. Do predictors of mortality in upper gastrointestinal bleeding include a weekend time of admission? Clin Gastroenterol Hepatol 2009;7:257-8.

16. Hearnshaw SA, Logan RF, Lowe D, Travis SP, Murphy MF, Palmer KR. Use of endoscopy for management of acute upper gastrointestinal bleeding in the UK: Results of a nationwide audit. Gut 2010;59:1022-9.

17. Marmo R, Koch M, Cipolletta L, et al. Predictive factors of mortality from nonvariceal upper gastrointestinal hemorrhage: A multicenter study. Am J Gastroenterol 2008;103:1639-47; quiz 48.

18. Ahsberg K, Ye W, Lu Y, Zheng Z, Stael von Holstein C. Hospitalisation of and mortality from bleeding peptic ulcer in Sweden: A nationwide time-trend analysis. Aliment Pharmacol Ther 2011;33:578-84.

19. Barkun A, Leontiadis G. Systematic review of the symptom burden, quality of life impairment and costs associated with peptic ulcer disease. Am J Med 2010;123:358-66 e2.

20. Reeves BC, Deeks JJ, Higging JPT, Wells GA. Chapter 13: Including non-randomized studies. Cochrane Handbook for Systematic Reviews of Interventions 2008-2009; Version 5.0.2.

21. von Elm E, Altman DG, Egger M, Pocock SJ, Gotzsche PC, Vandenbroucke JP. The Strengthening the Reporting of Observational Studies in Epidemiology (STROBE) statement: Guidelines for reporting observational studies. Lancet 2007;370:1453-7.

22. Shaheen AA, Kaplan GG, Myers RP. Weekend versus weekday admission and mortality from gastrointestinal hemorrhage caused by peptic ulcer disease. Clin Gastroenterol Hepatol 2009;7:303-10.

23. Chiu PW, Ng EK, Cheung FK, et al. Predicting mortality in patients with bleeding peptic ulcers after therapeutic endoscopy. Clin Gastroenterol Hepatol 2009;7:311-6; quiz 253.

24. Cooper GS, Kou TD, Wong RC. Use and impact of early endoscopy in elderly patients with peptic ulcer hemorrhage: A populationbased analysis. Gastrointest Endosc 2009;70:229-35.

25. Nahon S, Nouel O, Hagege H, et al. Favorable prognosis of uppergastrointestinal bleeding in 1041 older patients: Results of a 
prospective multicenter study. Clin Gastroenterol Hepatol 2008;6:886-92.

26. Barkun A, Sabbah S, Enns R, et al. The Canadian Registry on Nonvariceal Upper Gastrointestinal Bleeding and Endoscopy (RUGBE): Endoscopic hemostasis and proton pump inhibition are associated with improved outcomes in a real-life setting. Am J Gastroenterol 2004;99:1238-46.

27. Dorn SD, Shah ND, Berg BP, Naessens JM. Effect of weekend hospital admission on gastrointestinal hemorrhage outcomes. Dig Dis Sci 2010;55:1658-66.

28. Kohn A, Ancona C, Belleudi V, et al. The impact of endoscopy and specialist care on 30-day mortality among patients with acute nonvariceal upper gastrointestinal hemorrhage: An Italian populationbased study. Dig Liver Dis 2010;42:629-34.

29. Mose H, Larsen M, Riis A, Johnsen SP, Thomsen RW, Sorensen HT Thirty-day mortality after peptic ulcer bleeding in hospitalized patients receiving low-dose aspirin at time of admission. Am J Geriatr Pharmacother 2006;4:244-50.

30. Thomsen RW, Riis A, Christensen S, McLaughlin JK, Sorensen HT. Outcome of peptic ulcer bleeding among users of traditional nonsteroidal anti-inflammatory drugs and selective cyclo-oxygenase-2 inhibitors. Aliment Pharmacol Ther 2006;24:1431-8.

31. Soncini M, Triossi O, Leo P, et al. Management of patients with nonvariceal upper gastrointestinal hemorrhage before and after the adoption of the Rockall score, in the Italian Gastroenterology Units. Eur J Gastroenterol Hepatol 2007;19:543-7.

32. Button LA, Roberts SE, Evans PA, et al. Hospitalized incidence and case fatality for upper gastrointestinal bleeding from 1999 to 2007: A record linkage study. Aliment Pharmacol Ther 2011;33:64-76.

33. Murata A, Matsuda S, Kuwabara K, et al. Equivalent clinical outcomes of bleeding peptic ulcers in teaching and non-teaching hospitals: Evidence for standardization of medical care in Japan. Tohoku J Exp Med 2011;223:1-7.

34. Cattaruzzi C, Troncon MG, Agostinis L, Garcia Rodriguez LA. Positive predictive value of ICD-9th codes for upper gastrointestinal bleeding and perforation in the Sistema Informativo Sanitario Regionale database. J Clin Epidemiol 1999;52:499-502.

35. Andrade SE, Gurwitz JH, Chan KA, et al. Validation of diagnoses of peptic ulcers and bleeding from administrative databases: A multi-health maintenance organization study. J Clin Epidemiol 2002;55:310-3.

36. Cooper GS, Chak A, Lloyd LE, Yurchick PJ, Harper DL, Rosenthal GE. The accuracy of diagnosis and procedural codes for patients with upper GI hemorrhage. Gastrointest Endosc 2000;51:423-6.

37. Lopushinsky SR, Covarrubia KA, Rabeneck L, Austin PC, Urbach DR. Accuracy of administrative health data for the diagnosis of upper gastrointestinal diseases. Surg Endosc 2007;21:1733-7.

38. Muller T, Barkun AN, Martel M. Non-variceal upper GI bleeding in patients already hospitalized for another condition. Am J Gastroenterol 2009;104:330-9.

39. UK Comparative Audit of Upper Gastrointestinal Bleeding and the Use of Blood. British Society of Gastroenterology, 2007 <www.bsg. org.uk/pdf_word_docs/blood_audit_report_07.pdf> (Accessed July 2011).

40. Cooper GS, Kou TD, Wong RC. Outpatient management of nonvariceal upper gastrointestinal hemorrhage: Unexpected mortality in Medicare beneficiaries. Gastroenterology. 2009;136:108-14.

41. Rockall TA, Logan RF, Devlin HB, Northfield TC. Risk assessment after acute upper gastrointestinal haemorrhage. Gut 1996;38:316-21.

42. Blatchford O, Davidson LA, Murray WR, Blatchford M, Pell J. Acute upper gastrointestinal haemorrhage in west of Scotland: Case ascertainment study. BMJ 1997;315:510-4.

43. Stanley AJ, Dalton HR, Blatchford O, et al. Multicentre comparison of the Glasgow Blatchford and Rockall scores in the prediction of clinical end-points after upper gastrointestinal haemorrhage. Aliment Pharmacol Ther 2011;34:470-5.

44. Stanley AJ, Ashley D, Dalton HR, et al. Outpatient management of patients with low-risk upper-gastrointestinal haemorrhage: Multicentre validation and prospective evaluation. Lancet 2009;373:42-7

45. Lezzoni L. In: Risk adjustment for Measuring Healhcare Outcomes. Chicago: Health Administration Press; 2003.

46. Charlson ME, Pompei P, Ales KL, MacKenzie CR. A new method of classifying prognostic comorbidity in longitudinal studies: Development and validation. J Chronic Dis 1987;40:373-83.
47. Shingina ABA, Razzaghi A, Martel M, Bardou M, Gralnek I; the RUGBE investigators. The presenting INR as predictor of outcome in patients with upper non-variceal gastrointestinal bleeding. Aliment Pharmacol Ther 2011;33:1010-8.

48. Barkun AN, Bardou M, Kuipers EJ, et al. International consensus recommendations on the management of patients with nonvariceal upper gastrointestinal bleeding. Ann Intern Med 2010;152:101-13.

49. Gralnek IM, Barkun AN, Bardou M. Management of acute bleeding from a peptic ulcer. N Engl J Med 2008;359:928-37.

50. Barkun AN HI, Armstrong D, Dawes M, et al. Improving adherence to guidelines when managing non-variceal upper gastrointestinal bleeding: A national cluster randomized trial of a multifaceted strategy. Gastroenterology 2010;138(Suppl 1):5 (Abst).

51. Vreeburg EM, Snel P, de Bruijne JW, Bartelsman JF, Rauws EA, Tytgat GN. Acute upper gastrointestinal bleeding in the Amsterdam area: Incidence, diagnosis, and clinical outcome. Am J Gastroenterol 1997;92:236-43.

52. Spiegel BM, Vakil NB, Ofman JJ. Endoscopy for acute nonvariceal upper gastrointestinal tract hemorrhage: Is sooner better? A systematic review. Arch Intern Med 2001;161:1393-404.

53. Schmulewitz L, Proudfoot A, Bell D. The impact of weekends on outcome for emergency patients. Clin Med 2005;5:621-5.

54. Saposnik G, Baibergenova A, Bayer N, Hachinski V. Weekends: A dangerous time for having a stroke? Stroke 2007;38:1211-5.

55. Bell CM, Redelmeier DA. Mortality among patients admitted to hospitals on weekends as compared with weekdays. N Engl J Med 2001;345:663-8.

56. Nahon S, Pariente A, Latrive JP. Weekend admission does not influence the mortality of upper gastrointestinal bleeding caused by peptic ulcers: Results of a French prospective study of the association nationale des gastroenterologues des hopitaux generaux group. Clin Gastroenterol Hepatol 2009; 7:911; author reply 2.

57. Tsoi K, Pang SH, Chiu PW, Man YY, Lau JY, Sung JJ. The risk of ulcer-related death in relation to hospital admission on public holidays: A cohort study on 10,428 cases of upper gastrointestinal bleeding in Hong Kong. Gastrointest Endosc 2010;71:AB141 (Abst).

58. Jairath V, Logan R, Hearnshaw S, Travis S, Murphy M, Palmer K. Mortality from acute upper gastro-intestinal bleeding in the UK does it display a "weekend effect"? Gastroenterology 2010;138:21 (Abst).

59. Hopewell S, Dutton S, Yu LM, Chan AW, Altman DG. The quality of reports of randomised trials in 2000 and 2006: Comparative study of articles indexed in PubMed. BMJ 2010;340:c723.

60. Schulz KF, Altman DG, Moher D. CONSORT 2010 statement: Updated guidelines for reporting parallel group randomized trials. Ann Intern Med 2010;152:726-32.

61. Laine L, Spiegel B, Rostom A, et al. Methodology for randomized trials of patients with nonvariceal upper gastrointestinal bleeding: Recommendations from an international consensus conference. Am J Gastroenterol 2010;105:540-50.

62. Blatchford O, Murray WR, Blatchford M. A risk score to predict need for treatment for upper-gastrointestinal haemorrhage. Lancet 2000;356:1318-21.

63. Elixhauser A, Steiner C, Harris DR, Coffey RM. Comorbidity measures for use with administrative data. Med Care 1998;36:8-27.

64. Barkun AN Gasco A, Jewell D, Nevin K; the REASON Study Investigators. Management of nonvariceal upper GI bleeding (NVUGIB) after guideline publication: The Reason Study. Can J Gastroenterol 2006;20(Suppl A):80A (Abst).

65. Jairath V, Hearnshaw S, Brunskill SJ, et al. Red cell transfusion for the management of upper gastrointestinal haemorrhage. Cochrane Database Syst Rev 2010;(9):CD006613.

66. Hearnshaw SA, Logan RF, Palmer KR, Card TR, Travis SP, Murphy MF. Outcomes following early red blood cell transfusion in acute upper gastrointestinal bleeding. Aliment Pharmacol Ther 2010;32:215-24.

67. Elmunzer BJ, Pollack MJ, Trunzo JA, et al. Initial evaluation of a novel, prototype, forward-viewing echoendoscope in a porcine arterial bleeding model (with video). Gastrointest Endosc 2010;72:611-4.

68. Wong RC. Endoscopic Doppler US probe for acute peptic ulcer hemorrhage. Gastrointest Endosc 2004;60:804-12.

69. Giday SA, Krishnamurty DM, Liang D, et al. A long-term randomized controlled trial of a novel nanopowder hemostatic agent for control of severe upper gastrointestinal bleeding in a porcine model. Gastrointest Endosc 2010;73(Suppl):A938 (Abst). 


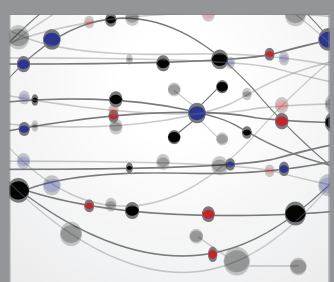

The Scientific World Journal
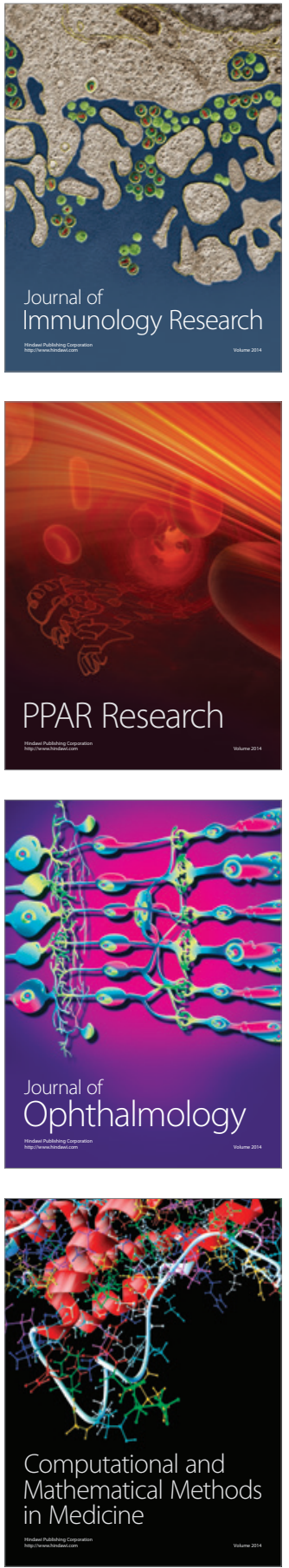

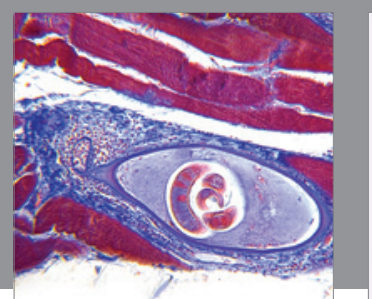

Gastroenterology Research and Practice

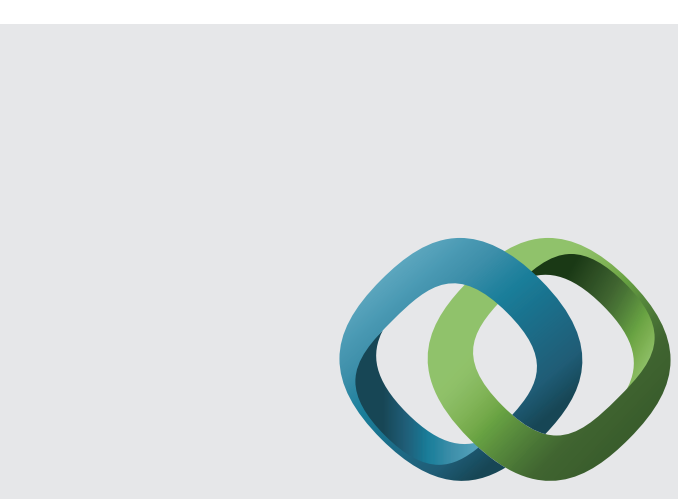

\section{Hindawi}

Submit your manuscripts at

http://www.hindawi.com
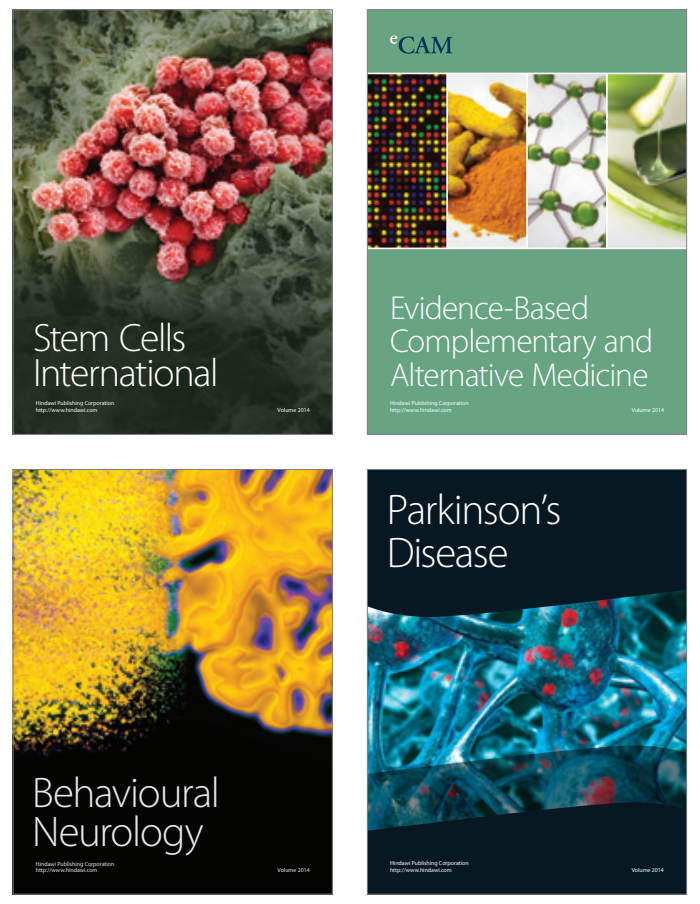
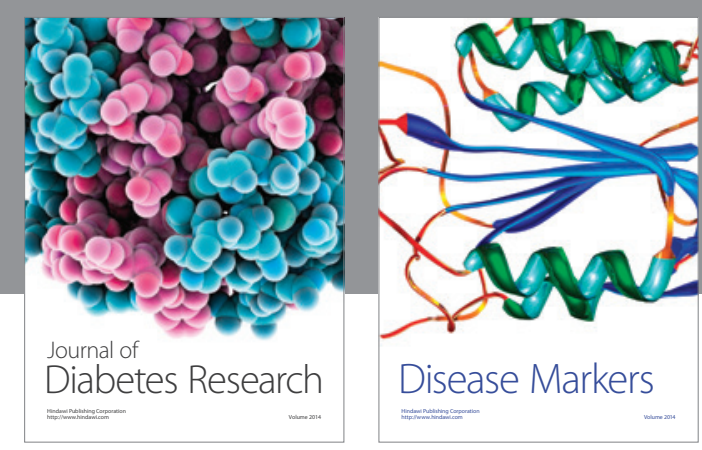

Disease Markers
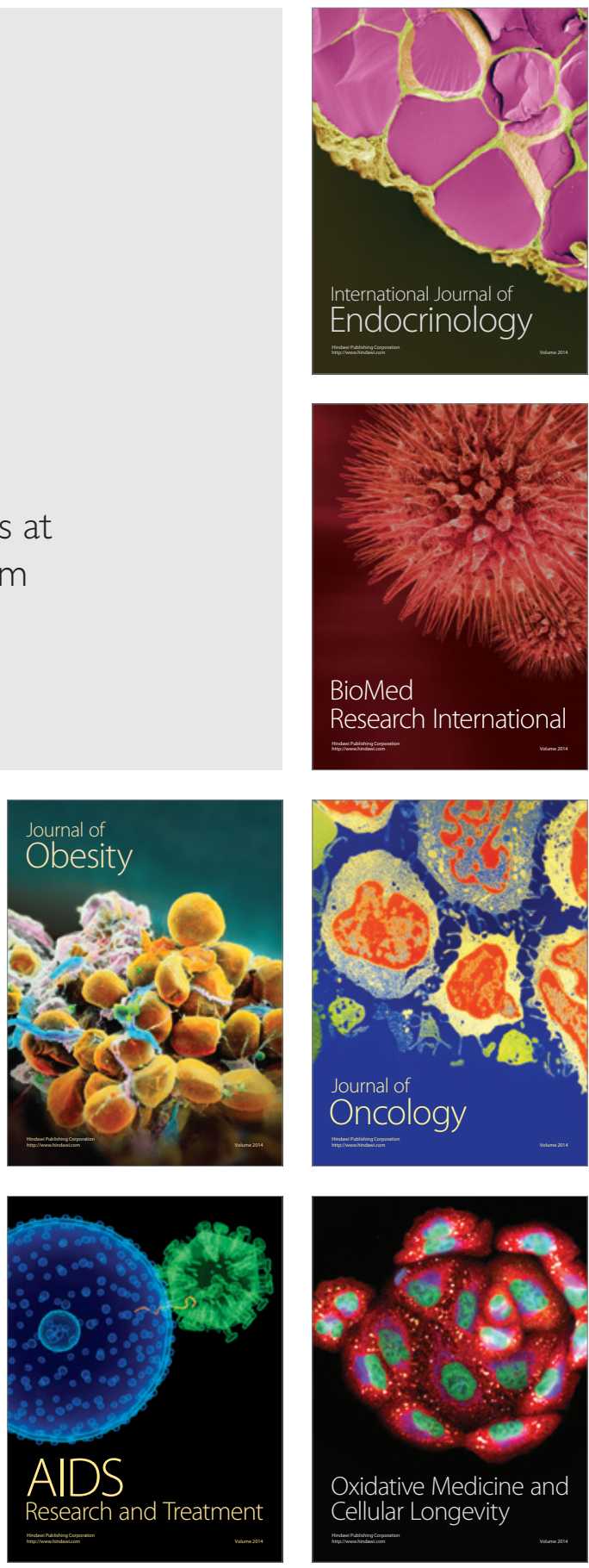